\title{
Humanities and Social Sciences Scholars on the Campaign Trail: Between Expertise and Prophecy
}

Analysing French HSS Scholars' Press Appearances In the 2014 European Election Campaign

Les sciences humaines et sociales en campagne: entre expertise et prophétie. Les interventions des chercheurs dans la presse durant les élections européennes de Mai 2014 (Le Monde, Le Figaro, Libération)

Constantin Brissaud and Éric Brun

Translator. Jean-Yves Bart

\section{OpenEdition}

\section{Journals}

Electronic version

URL: https://journals.openedition.org/bssg/670

DOI: $10.4000 /$ bssg.670

ISSN: 2490-9424

Publisher

Presses universitaires de Vincennes

Electronic reference

Constantin Brissaud and Éric Brun, "Humanities and Social Sciences Scholars on the Campaign Trail: Between Expertise and Prophecy", Biens Symboliques / Symbolic Goods [Online], 8 | 2021, Online since 20 May 2021, connection on 23 July 2021. URL: http://journals.openedition.org/bssg/670 ; DOI: https://doi.org/10.4000/bssg.670

This text was automatically generated on 23 July 2021

Biens Symboliques / Symbolic Goods 


\section{Humanities and Social Sciences Scholars on the Campaign Trail: Between Expertise and Prophecy}

Analysing French HSS Scholars' Press Appearances In the 2014 European Election Campaign

Les sciences humaines et sociales en campagne : entre expertise et prophétie. Les interventions des chercheurs dans la presse durant les élections européennes de Mai 2014 (Le Monde, Le Figaro, Libération)

Constantin Brissaud and Éric Brun

Translation : Jean-Yves Bart 
Fig. 1.

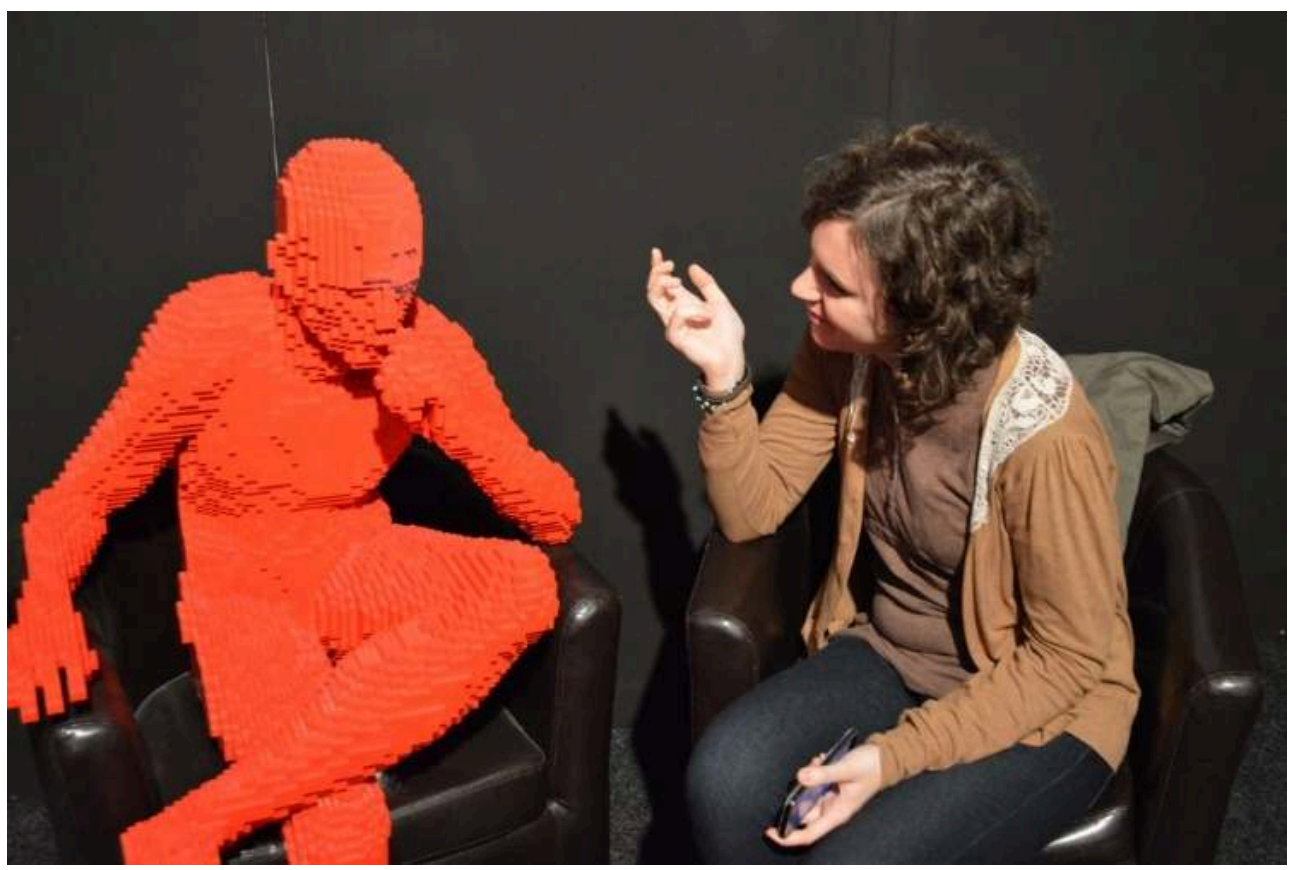

"Lego interview" by Matt Brown

Source: Flickr

\section{Introduction}

1 In France, just as the use of the term "intellectual" has been instrumental in the constitution of a very heterogeneous social group since the Dreyfus affair (Charle 1990), forms of engagement on the part of intellectuals have historically varied and clashed (Matonti \& Sapiro 2009). Beginning in the second half of the twentieth century, which saw, in particular, the institution of the opinion piece format (Jeanpierre 2016), the introduction of sections devoted to "points of view" and "ideas" in the print press and the launch of TV shows hosting debates between intellectuals (Lensing-Hebben 2008) have considerably changed the repertoires of action at their disposal as well as the logics through which their interventions gain exposure and legitimacy.

While the analysis of recent mutations in intellectual life has generally pointed out "the victory of the journalistic field, which has taken on [...] a genuine function of jurisdiction over the intellectual world" (François \& Neveu 1997: 38; see also Bourdieu 1984), another major twentieth century trend also deserves to be highlighted and examined: the increased specialization of knowledge, against the backdrop of a competition for the monopoly over areas of expertise (Abbott 1988). Starting in the late nineteenth century, as new elites of the Republic emerged to meet the State's needs for scholarly expertise, (Delmas 2006), the rise of the scientific paradigm and the institutionalization of several disciplines (Sapiro, Brun, Fordant 2018) resulted in a new competition with philosophy and the "humanities" (Soulié 2013; Joly 2017). These evolutions have arguably been conducive to the development of a specific form of political engagement, that of the "expert", whose input in public space is given in the name of a specialist competence that is institutionally recognized ${ }^{1}$, in contrast with the engagement of the "universalist" or "total" intellectual, whose contributions are made 
as an individual, in the name of broad values (freedom, truth, justice, beauty...) and may pertain to any (political, economic, social...) topic in which such values could play a role.

3 This article aims at reconsidering this distinction, as well as another one, made by Max Weber - and adapted, after Bourdieu (Bourdieu 1971) imported it into his field theory, by Gisèle Sapiro in her typology of the forms of engagement of intellectuals in the twentieth century (Sapiro 2009) - between the ideal-types of the "priest", whose authority is derived solely from his relationship to an institution, and of the "prophet", whose authority comes from individual charisma. It will do so by examining a specific category of intellectuals - academics and researchers in the humanities and social sciences (HSS) ${ }^{2}$. As they are accredited by institutions that confer scholarly authority on their members, and for the most part are paid by the State, the scholars under study here might appear to fall under the category of "priests", and of its secularized form in the intellectual field, the expert, "who makes his diagnosis following predetermined procedures, whereas recognition based on charisma [conversely] predisposes to prophecy" (Sapiro 2009: 11). The academic division on the basis of specialized "disciplines" of knowledge, endowed with their own corpuses of concepts, methods and objects of study (Gingras 1991; Heilbron 2004; Boutier et al. 2006), likewise puts them - with some exceptions, such as philosophers - in the category of the "specialized" experts, as opposed to the "universalist" intellectuals.

4 Are the modalities of their political engagement in accordance to what one might expect of them in light of these characteristics, then? While the term "expertise" is generally associated with the response to a commission from an authority - often political or economic (Memmi 1989) - HSS scholars clearly have a wider array of modes of intervention at their disposal. Additionally, they differ from the ideal-type of the priest in several important respects: their history, crystallized in a specific status (most importantly the lecturer-researcher [enseignant-chercheur] status as defined in 1984) grants them a degree of independence; in principle, as civil servants, they are immune from the vagaries of economic demand, while they also are exempted from the obligations pertaining to the freedom of expression of civil servants under the devoir de réserve (duty of discretion) ${ }^{3}$. The repertoire of political interventions at their disposal thus comprises the possibility of publicly expressing themselves in the press, including on political matters and/on during electoral campaigns. Our analysis precisely focuses on this latter type of intervention.

5 How can the press interventions of HSS scholars be characterized? Is the "expertise" category suitable to describe this type of political engagement and to grasp its implications? Several studies on press opinion pieces have shown not only that their authors are largely academics and researchers from various HSS disciplines (Désintox 2004; Pinto 2002; Jeanpierre \& Mosbah-Natanson 2008), but also that uses of this format generally reflect a 'universalist intellectual' type of engagement. This article will update these studies by examining a new case - that of the contributions of HSS academics and researchers in three of the main French daily newspapers on the occasion of the European election that was held on Sunday 25 May 2014 in France and between 22 and 25 May in other EU countries. We will do this by shifting the focus of observation in several ways, starting by considering, alongside opinion pieces, another type of press articles: interviews (see Box "Building the corpus"). 
In what capacities were these scholarly interventions made during the electoral campaign? How are claims at scholarly expertise reflected in the form and content of these interventions? Can, say, a specification of the subjects addressed or of the ways of addressing them be observed according to the discipline of the scholars under study? Is this enough for their contributions to qualify as "scholarly" discourse? In the following, we will point to forms of legitimation and specialization that echo the idea of "scholarly expertise," but that ultimately do not prevent the fact that the same academics and researchers, who are already most present in the media, are repeatedly invited to express themselves on a variety of subjects, nor the instrumentalization of academic or scientific "titles" by authors who are situated outside of the academic field. Correlatively, we also observe the adoption of more classical "universalist" intellectual postures, and the recourse to expressive registers that are more akin to "prophetic" appeals to protect purportedly threatened values than to scholarly discourse.

Building the corpus

We collected and analysed the interventions of HSS academics and researchers published between 1 and 31 May 2014 in three prominent national daily French newspapers (Le Monde, Libération, Le Figaro), chosen for their generalist approach and relatively wide political spectrum (Libération is generally considered leftwing, Le Monde centrist and Le Figaro right-wing). We systematically retained articles that directly or indirectly addressed the current European election (which includes articles whose publication was objectively linked to that current news item although they did not explicitly dealt with Europe or the election as such). To build the corpus of articles, we conducted keyword searches on the websites of the three selected newspapers, consulted the Europresse and Factiva databases, and, in the case of Le Monde, systematically went through paper copies across the entire period. This corpus was then subjected to quantitative analysis (using the textual analysis software Iramuteq) and qualitative analysis (close reading); biographical data on the authors were also collected.

The choice of the newspapers and of the study period were determined by a research subject that was unrelated to this article, pertaining to the emergence of a European intellectual space ${ }^{4}$ (Duller et al. 2017). It should be noted, however, that choosing three newspapers while excluding other media (other papers, radio or TV shows, blogs, social media...) would have been problematic if the purpose had been to retrace the space of position-takings on the European construction process. This is in no way the intent here, as the goal of this particular research is to analyse the conditions and constraints of the implementation of a particular type of political engagement at the disposal of "scholars" - public interventions in the French generalist news press. As it turns out, it is preferable that the selection of articles is derived from a news sequence rather than from a single controversy (as is the case in Duval et al. 1998). Indeed, the relative homogeneity of the corpus in terms of the type of public intervention under study is offset by the diversity of subjects addressed in said interventions.

Still, this article presents a case study that is as such intended to serve as the basis for further comparisons, particularly with public interventions of HSS scholars in 
other forms and other media, and in different circumstances. Most notably, our analysis would benefit from further study on the operations of selection and formalization of "scholarly" interventions by journalists. In the meantime, here, we have tried to evidence some signs of journalistic expectations and/or interventions, which may for instance be visible in the differences between two versions of the same article (paper and online), or in the highlighting of a particular author's name within a group of authors.

Regarding the selection of authors, we opted for a broadly inclusive approach. Indeed, our corpus contains a number of authors whose categorization as "HSS academic or researcher" is objectively problematic, seeing as it includes magistrates, consultants, journalists, etc. who also teach in a university or a top school and/or do research in organizations like think tanks. We decided not to exclude them upfront for the purpose of accounting for the permeability of boundaries between fields and for self-presentation strategies (Collovald 1988). In other words, we chose not to predefine the legitimate boundaries of the "scholar" category so that we were able to observe the power relations through which claims to admission in that category are regulated.

Our corpus includes 87 authors and 81 articles. Out of these, 39 were published in Le Monde's paper and/or online editions, 27 in Libération and 15 in Le Figaro; 45 were published during the three weeks that preceded election day in France (Sunday 25 May) and 37 during the week after. Many articles were published before and after the election weekend in France. More than half are opinion pieces (47), signed by individual authors, or, more rarely, by groups of authors. Interviews with scholars, who we consider here as authors of these articles, are also numerous (25). The corpus also includes five articles that were part of a regularly scheduled column and four articles of an analytical nature (examining pre- or post-electoral opinion polls), differing from the opinion piece genre in that, first, they were not published in the pages generally reserved for such pieces, and second, they were not intended to express an "opinion", but rather to present a distanced and objective analysis.

\section{1. "Expertise" as a Mode of Legitimation}

7 The signatures of the articles in our corpus mention either a disciplinary affiliation ("economist," "politologist," "doctor of political science," "constitutional law scholar," "historian of ideas," etc.) or a job title ("professor," "lecturer," "director of studies," etc.), in an institution whose name conveys scholarly ambition ("Sciences Po," "University," "Institute of Research...," etc.), or both.

8 In some cases, the scholarly title merely enhances a symbolic capital that is already contained in the author's name. In a reflection of the forms of legitimacy that underpin access to the generalist press, only the economists Jean-Paul Fitoussi, James K. Galbraith and Joseph Stiglitz were for instance named in the title of a joint opinion piece published in Le Monde. The other nine signatories, whose names would ring less familiar to the French readership, were tacked on in a short note at the end of the article. 
Still, even for the most famous authors, the mention of an institutional title and/or of a disciplinary affiliation appears to be required. While we cannot entirely dismiss the possibility that academics and researchers make public interventions in the press without using these titles (as a result of which we may have failed to identify them), all signs point to this being very rare. Even if some might want to speak out publicly as "simple citizens," they cannot easily renounce the titles that give them access to public expression (Siméant 2002: 35).

In some cases, a "specialization" in a given subject is also highlighted. In a little over 40 percent of articles in our corpus, the article's signature features the title of one or two of the author's books alongside their name, an addition that further guarantees their authority on the topic in question. In a few, seemingly more rare cases, a thematic specialization is mentioned explicitly. Sociologist Vincenzo Cicchelli is for instance introduced as having "worked on cosmopolitan socialization," Yves Bertoncini as having "written many books on European matters," Vincent Tournier as a "specialist of youth and political matters," etc.

11 These practices of conferring further authority to the author by mentioning a book and/or a thematic specialization do not appear to be distributed entirely randomly. In particular, they are noticeably more frequent in the case of interviews. This suggests that journalists, when they seek to justify their selection of a researcher or an academic for an interview, tend to highlight the excellence of their expertise. This legitimation of press interventions is combined with a frequent association between some areas of expertise and some scholarly disciplines.

\section{The Importance of Scholarly Disciplines}

In our corpus of articles, we observed a fragmentation of subjects, so that, in lieu of a single controversy pertaining to European matters, we found a number of different, weakly interconnected debates. These took place in two successive junctures. In the first juncture (before 25 May - election day), the articles mainly addressed the reform of European institutions, the single currency, economic policy, European identity, and, without this being a predominant theme, "populisms" and "extreme" politics in Europe. On the other hand, after the election results were announced, most of the articles were devoted to the analysis of the Front National' $\mathrm{s}^{5}$ improved electoral scores in France, of its causes and implications, of what should be done to stop its rise, and of French politics in general (what will become of the Parti Socialiste ${ }^{6}$ ? How will the UMP move on? etc.).

Using the Iramuteq software (see box "Iramuteq's functionalities"), we built vocabulary classes that evidence this division on the basis of different angles or subjects (Figure 2). The first two classes represent the terms of the post-electoral debate: class 2 ( $24 \%$ of the total of words used) mainly includes the vocabulary of the French political field (under its partisan and electoral definition) and Class 1 (18\%) more largely refers to social problems (and/or social conflicts). Classes 4 and 3 refer to pre-electoral debates respectively on economic policies (Class $4: 16 \%$ ) and the European construction (the enlargement of the European Union, the Ukrainian question, geopolitics, etc.) (Class 3: $24 \%$ ). Lastly, Class 5 , which includes $18 \%$ of all words used in the corpus, contains the vocabulary of European institutions - including, notably, the terms "Council," 
"executive," and "Commission" - and the names of the two candidates to the latter institution's presidency: Jean-Claude Juncker and Martin Schulz.

Fig. 2.

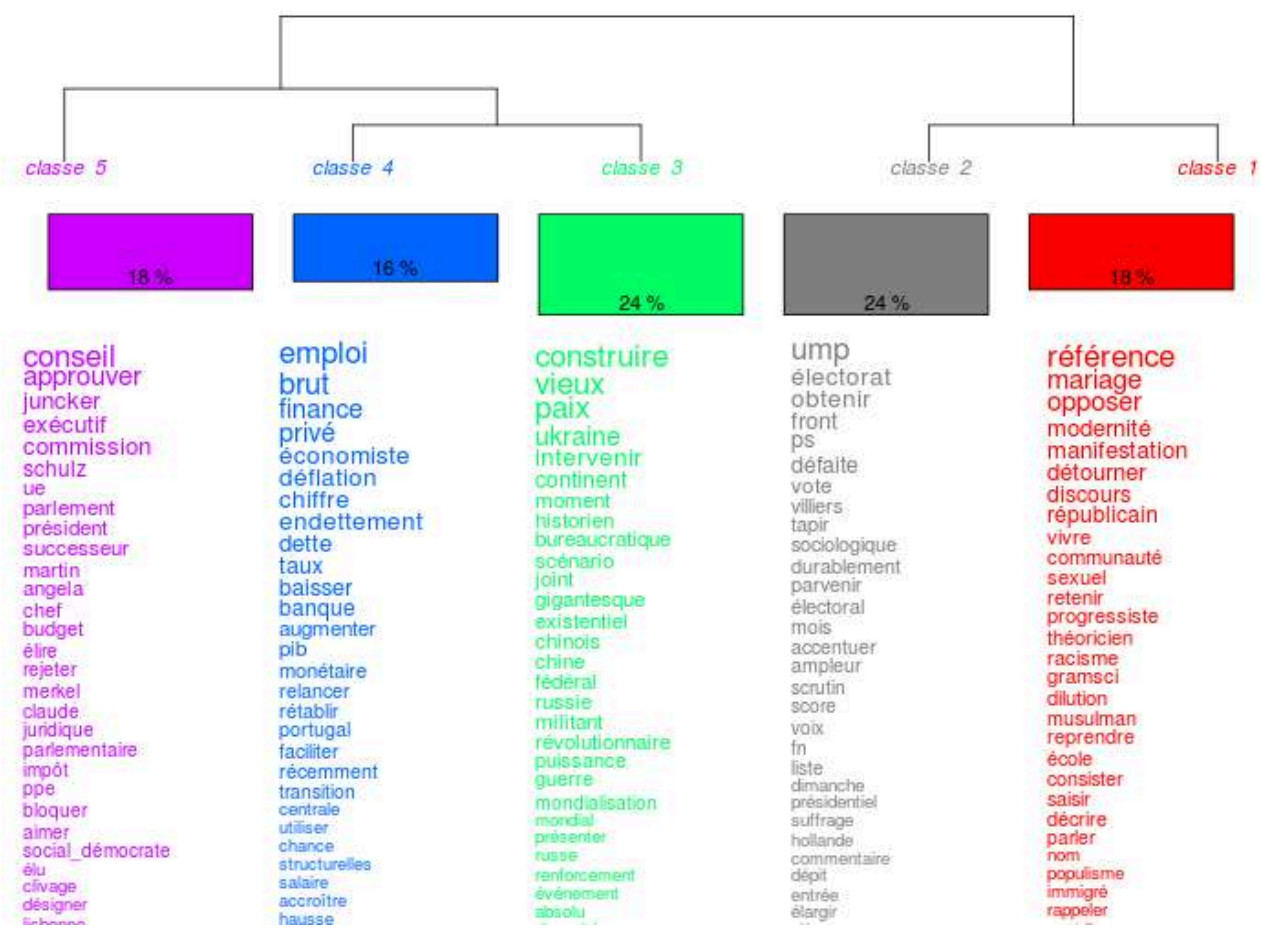

Descending hierarchical clustering (DHC) of the terms employed in the articles Source: Constantin Brissaud and Éric Brun

14 The topics addressed in the articles tend to vary according to the author's discipline. Economists, for instance, primarily discuss economic and monetary policy questions: their articles assess the possible effects (positive, negative, or insufficient) of exiting the Eurozone. The pertinence of the economic, budgetary and monetary policies (in terms of economic crisis, growth, employment, etc.) put in place by the European Commission or the Central Bank, or implied by the EU treaties, is also discussed.

As for the themes related to European construction and/or the operation of European institutions, they are addressed by a significant fraction of the few foreign authors in our population - such as the political scientist Ivan Krastev (interviewed by Le Monde on the EU's enlargement), the linguist Raffaele Simone (interviewed by Libération on "Europe's current crisis"), or the literary theorist Tzvetan Todorov (who penned a piece calling to "revolutionize European institutions" in Le Monde) -, mainly by political scientists and specialists of "European matters", and by most Sciences Po Paris lecturers in our population.

Political scientists also tend to hold a monopoly over a type of articles that consists in surveying the new state of French politics in the wake of the electoral results (what will become of the UMP? Who will be the PS candidate in 2017?, etc.). They tend to have a similar monopoly on the interpretation, supported by figures, of polls and electoral results (these articles are published in the main pages of the papers, not those on "debates" or "points of view"). In addition to the contributions of Martial Foucault and Pascal Perrineau (both members of Cevipof, one of Sciences Po's laboratories, which 
developed a specialty in electoral analyses), another researcher in political science, Jean-Yves Dormagen, penned one such article in Libération upon the announcement of the results as the founder of the Observatoire du changement politique ${ }^{8}$.

As for the sociologists, those who wrote articles before the electoral results mostly discussed "European identity", a theme also addressed by philosophers. In the few days following the election, many published articles on the far-right and the causes of its rise. This was the case of Luc Boltanski and Arnaud Esquerre, Philippe Corcuff, Raphaël Liogier, Michel Maffesoli, Michel Wieviorka, as well as political scientists with a more sociological approach to politics, such as Sylvain Crépon et Alexandre Dézé. Sociologists shared this theme with representatives of other disciplines: geographers, and a few economists and philosophers. A number of media specialists, like François Jost and Philippe Riutort, more specifically wrote about the media's contribution to the FN's scores.

This distribution of these articles' subjects of choice based on their authors' discipline is overall characterized by the presence of three groups: the economists, the political scientists, and a group of representatives of various human sciences (sociology, philosophy, history, geography...). This can also be observed in the discipline-based variations of the vocabulary employed in the articles. The analysis of two factorial designs based on the terms more or less frequently used by the authors thus reveals sharp disciplinary contrasts.

Iramuteq's functionalities

We obtained figure 2, 3 and 4 using the Iramuteq textual analysis software, developed by Pierre Ratinaud at the Laboratory for applied social science studies and research of the University of Toulouse 3-Paul Sabatier. We entered all article texts into the software, and assigned them tags (author name, date, and newspaper in which the article was published). Iramuteq performed a factorial correspondence analysis on a contingency table displaying the words found in the articles and the articles (or their authors' names). Then, the authors' names were projected on a factorial design on the basis of which words they used. This means two authors located next to each other on the factorial design share the use of large numbers of words. "Words" here must be understood as lemmas: each word was recorded in root form to be associated with other words in the same family. For instance, "elect" (and its conjugated forms), "elections, "election", "electors" and "elector" were grouped within the same family through lemmatization. Additionally, the most common words in the French language, such as the equivalents of "from", "and", "to", etc., were excluded from the analysis and therefore did not contribute to the construction of the axes (for more detail on lemmatization, see Mayaffre 2005). Iramuteq also allowed us to perform a descending hierarchical clustering (DHC) of the terms used in the articles. The words most often found together in the same texts constituted a DHC class, which can be analysed as a theme in the corpus. For each class, the analysis of characteristic text segments focuses on the most typical article excerpts for the class, and by extension on the most characteristic dates and authors in the class.

On the left part of Figure 2, we essentially find the language of economists ("taux [rate]", "emploi [employment]", etc.), matching the position of the majority of 
economists in our population on Figure 3. Likewise, in the upper-right corner of Figure 2, we find a vocabulary associated with French politics, especially electoral politics ("suffrage," "vote," etc.), with references to past ("2009") and future electoral landmarks ("2017," "présidentiel [presidential]"), parties ("UMP," "Frontiste [member of the FN party]") and strategies ("allié [ally]"), similarly matching a strong concentration of political scientists on Figure $3^{9}$; the lower-right corner has a higher representation of scholars from other human sciences (including sociologists, philosophers and psychoanalysts like Stéphane Habib), sharing the use of terms pertaining to society ("génération [generation]," “ jeunesse [youth]," "marriage [marriage]") and communication ("information," “discours [discourse]," "media"...).

Fig. 3.

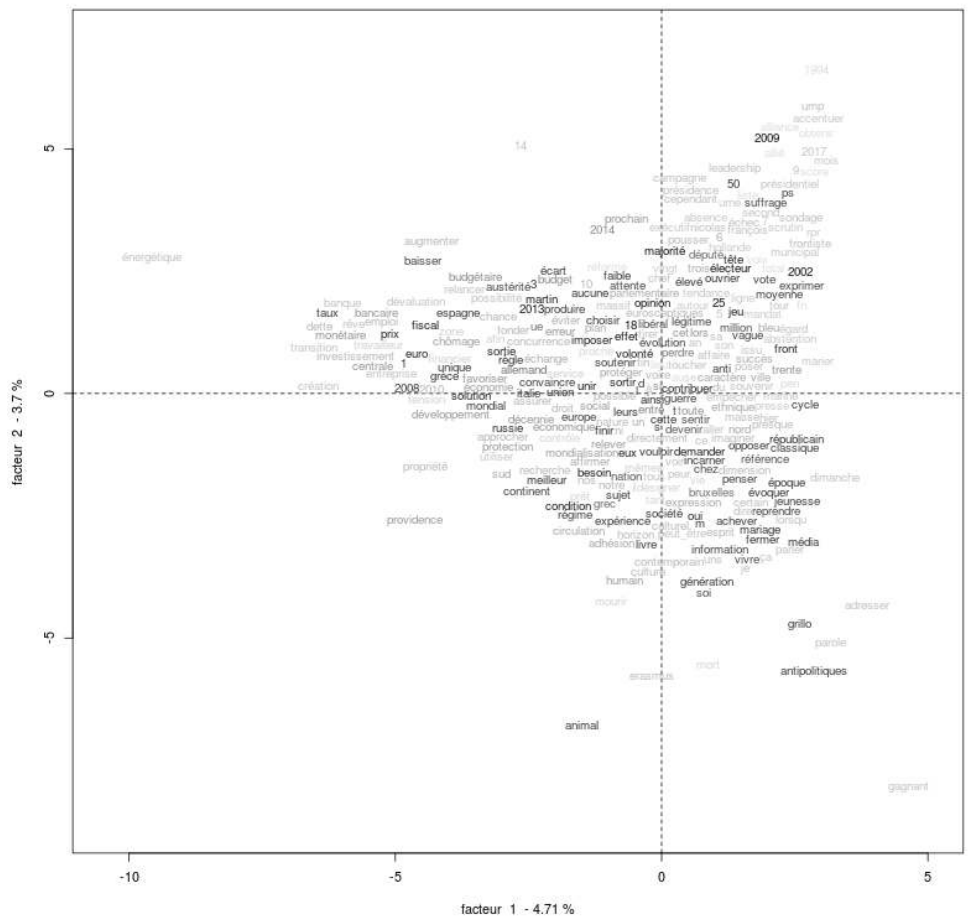

Factorial correspondence analysis (FCA) of the terms employed in corpus articles Source: Constantin Brissaud and Éric Brun 
Fig. 4.

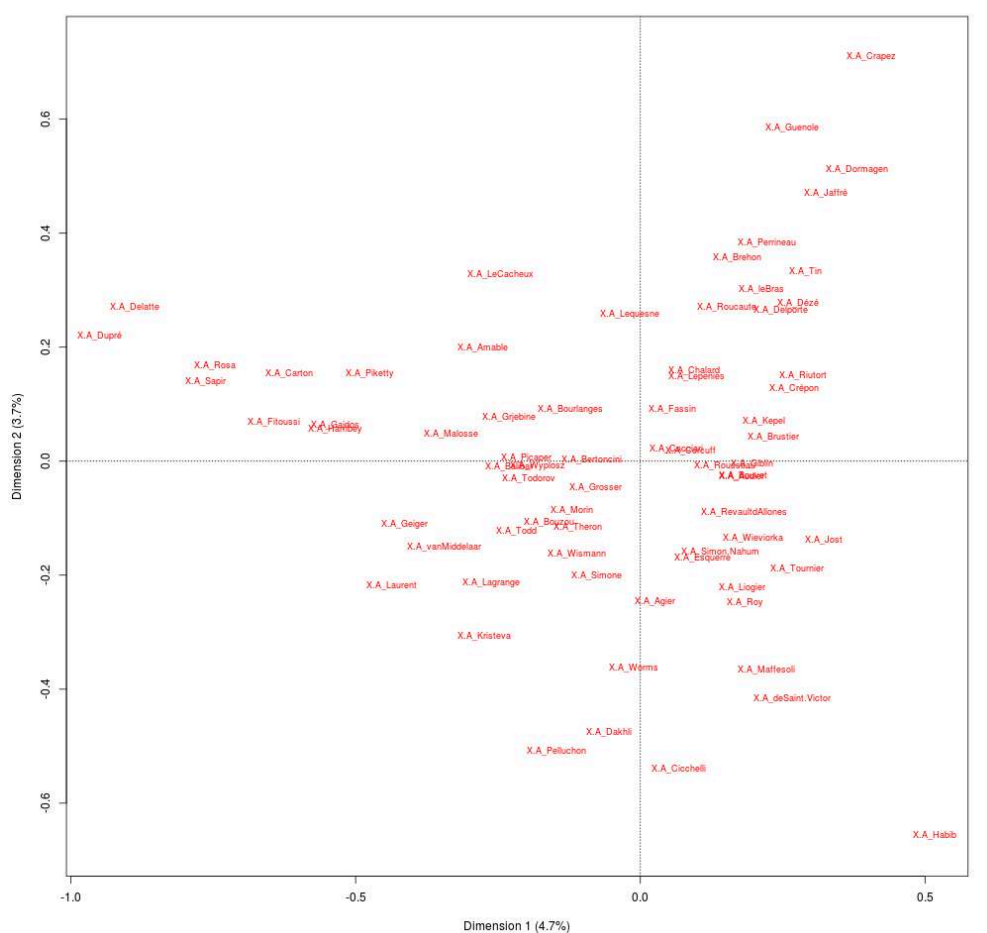

Factorial correspondence analysis (FCA) of the authors based on the terms employed in their articles Source: Constantin Brissaud and Éric Brun

Are we to conclude from this relative match between the authors' disciplines of origin and the subjects/vocabularies of the articles that nowadays, HSS academics and researchers who write for the press, tend to adopt the model of the "expert", specialized in a given discipline or subject? Some perspective is in order here: the discipline-based distribution of themes and vocabularies, while it reflects the division of areas of expertise between the disciplines, in no way prevents the adoption of more traditional postures of engagement in the articles under consideration. This is shown by an analysis of the argumentative registers employed.

\section{Between Recommendations and Prophecies}

Even though the articles in our corpus were published during an electoral campaign, politics generally features in them in a somewhat muted manner: in few of them, their author takes an explicit stance on the most directly partisan issues ${ }^{10}$. They more often contain recommendations for the benefit of policymakers and/or public opinion, sometimes in support of clear reforms, and sometimes of broader political reorientations: "democratizing European institutions", "creating a Eurozone parliament", changing the "ideological software" of the left, printing more money, doing away with "poll journalism", etc. In such cases, the authors resort to a directive or incentivizing register, using phrases such as: "Member States should have the courage of...," "let us dare to...," "for a...," "we ask that...," "only by... will future initiatives be possible...," etc. 
While this register of recommendation can be interpreted as the consequence of the historical process of the academic field's autonomization from the political field (Bourdieu 1991; Duclert 1999; Matonti 2002), we cannot infer from this that the press interventions of researchers and academics comply with the codes of scientific production. Both opinion pieces (which reflect a conception of public debate as the confrontation of multiple opinions, as opposed to the methodical and controlled objectivization of truths) and interviews with an "expert" are genres whose codification is primarily dependent on constraints that are specific to the journalistic field (concision, clarity, topicality of the subject, etc.). Thus, they are seldom conducive to implementing the rules of scientific evidence ${ }^{11}$. (which admittedly is not a guarantee of scientificity in itself), with the exception of the few articles on economic policy and of those offering a "scholarly" commentary on polls and electoral results. When they are included, illustrations are generally photographs (more rarely, drawings) that merely symbolize the subject under discussion: a European flag, the euro logo " $€$ ", shots of the European Parliament, and numerous portraits of Marine Le Pen (president of the FN party) after the results were announced.

Even though the texts are often informed by the author's disciplinary habitus (in terms of the vocabulary they use and of the subjects they discuss), they rely on argumentative registers that are far from the form of a "dispassionate" diagnosis. The articles in our corpus frequently include formulations that echo the figure of the "prophet," calling the public's attention to the meaning of an ongoing crisis, more than that of the "priest," establishing a diagnosis based on stabilized procedures. This is especially the case for articles published after the election, with a significant fraction of sociologists (and philosophers) among the authors: amid a widespread sense of crisis - this was the first time that the Front National was in the lead in a nationwide election (with nearly $25 \%$ of votes), ahead of the UMP (21\%) and the ruling Parti Socialiste (14\%) - a prophetic tone prevailed in most articles. They analyse the FN's scores as an imminent peril for French democracy (the political spectrum has been "shattered," the nation "plunged in a state of electoral depression," "democracy is withering," "a fracture," a "major danger," "it is becoming urgent to...," "before it is too late," etc.). Discourses across the board are mainly intended to ward off this peril - responding to the crisis by giving it a meaning (a "sign of the times") and a direction ("this is no longer a time to...," "sooner or later, society...," "the time for the left's ideological reconstruction has probably come"). In the latter example, the word "probably," printed in the text, has been removed from the title of this article/interview published by Le Figaro, which suggests that journalistic expectations contributed to reinforcing this prophetic dimension. 
Fig. 5.

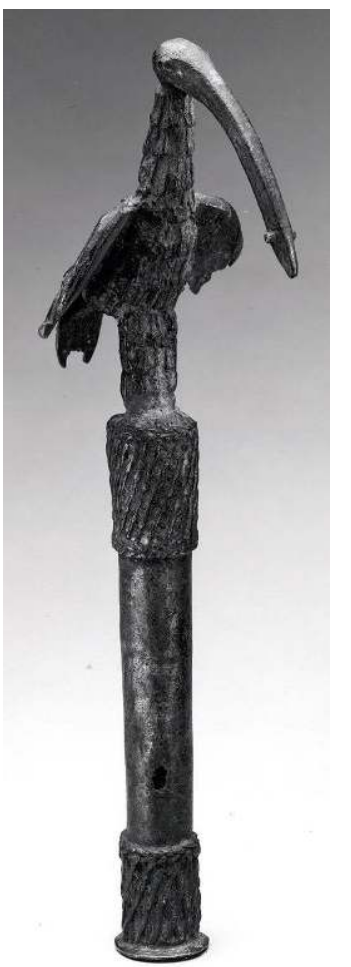

"Bird of Prophecy (ahianmwen-oro) " (music instrument, Nigeria, 16th-19th century)

Source: New York, Metropolitan Museum

\section{An Outlet for Powerful Men?}

In the same way that "the question of the definition of the intellectual, or, rather, of specifically intellectual work, is inseparable from the question of defining the population which can be allowed to participate in this definition" (Bourdieu 1988: 269), analysing interventions by HSS scholars in the press requires taking into consideration not only the format's constraints, but also the properties that characterize the population of authors in question.

To some extent, this population includes diverse backgrounds, which is evidenced for instance by the presence of often younger individuals with little public exposure or recognition outside of academia, and whose scholarly title is the only justification for their public intervention. Their numbers are however fairly low ${ }^{12}$, and in any case certainly not high enough to call into question the long-established observation of the high social selectivity that characterizes the access to the national generalist press.

Indeed, the academics and researchers in our population largely come from some particular fractions of the academic field: they generally have already had long careers (their average age was 57 at the time of the study, and individuals aged over 60 accounted for more than half of the authors); they are male (in $91 \%$ of cases) and they often hold several titles concurrently, thereby occupying a position at the intersection of the intellectual field and the field of power (Bourdieu 2020; Denord et al. 2011: 24). Thus, out of the 77 individuals who are French or work in France, and form the vast majority of the authors listed in our corpus (see box "A space for European debate?"), 
26 have an entry in their name in the Who's who in France (34\%), 22 have been awarded the Legion of Honour (the highest French order of merit; nearly 30\%), and several are also participants in a variety of organizations in charge of State expertise: ministerial committees, the Conseil d'analyse économique (CAE), the Haut-Conseil à l'intégration, the Haut-Conseil de la famille, etc. Additionally, over half of the authors conduct research in the institutions perceived as the most prestigious in the human and social sciences in France. Conversely, only 14 percent are affiliated with a non-Parisian university. (Figure 5).

Fig. 6.

\begin{tabular}{c|c|c} 
Main Academic Affiliation & Number & $\%$ \\
\hline CNRS, EHESS, ENS & 21 & 27 \\
\hline IEP & 18 & 23 \\
\hline Parisian University & 19 & 25 \\
\hline Non-Parisian University & 11 & 14 \\
\hline Other & 8 & 11 \\
\hline Total & 77 & 100 \\
\hline
\end{tabular}

Distribution (in percent) of French authors by academic affiliation Source: Constantin Brissaud and Éric Brun

A Space for European Debate?

A dozen of individuals in our population are not French nationals (14\%); there are also a few who are but work abroad. This remains a fairly low level of internationalization considering the corpus was built during a European election month. It is worth noting that the foreigners in our corpus were in most cases generally asked to contribute in the form of interviews (i.e., unsolicited opinion pieces) and translations of articles published in foreign newspapers. Additionally, the national focus of debates was particularly strong after the announcement of the results: only a few articles then adopted a more international angle, like one penned by Charles Wyplosz (a professor of international economics at the Graduate Institute in Geneva, Switzerland).

Most notably, far from being complete unknowns in France at the time of the election, several of these foreign contributors already had a book published in French by a prominent publisher (Flammarion in 2006 for Ian Buruma, Albin 
Michel in 2012 for Heinz Wismann - also a director of studies in a prominent Parisian academic institution, the EHESS -, Gallimard for Luuk Van Midelaar, Gallimard and Seuil for Wolf Lepenies, etc). Likewise, many of them (Krastev, Buruma, Müller, de Schütter, Galbraith, Stiglitz) had also contributed to Project Syndicate. ${ }^{13}$ The importance of intermediaries (publishers, papers and columnists), which is likely to explain the presence of these authors in the French press, suggests that this limited opening of the national press to a few foreign intellectuals cannot be considered as proof of the existence of a European intellectual space: on the contrary, it needs to be situated within the context of national-level publishing and journalistic strategies.

Also, all HSS disciplines are not equally represented in our population of authors. If we consider solely the discipline mentioned in the author's signature or presentation which leads, first to excluding around thirty authors for whom there is no mention of a discipline, and second, to count individuals multiple times when they are affiliated with multiple disciplines - economics come first (13), ahead of philosophy (12), political science and sociology (11 each), and history (7), with geography (2), demography (2), psychoanalysis (2) and anthropology (2) trailing far behind.

Admittedly, we have shown that some subjects tend to be primarily discussed by scholars of specific disciplines, which means that the juncture in which we carried out our study necessarily affects the respective ranks of scholarly disciplines among our population of authors. However, this is not an explanation for the very wide gap between the most frequently and the most rarely represented disciplines, especially considering that the disciplines that stand out here also stood out in other studies on press opinion pieces, whose corpus was not limited by the European electoral juncture (Jeanpierre \& Mosbah-Natanson 2008). This may therefore reflect the unequal distribution, depending on the disciplinary affiliation, of the likelihood of being considered an "expert" by journalists.

Lastly, beyond this (very relative) diversity of disciplinary affiliations, our population is characterized by a high proportion (36\%) of alumni of the prestigious Institutes of Political Studies (IEP), especially the most famous of them; Sciences Po Paris. This applies chiefly to the political scientists of the corpus, but also to many economists (André Grjebine, Gérard Lafay, Jacques Sapir...), several sociologists, a historian and a demographer. Possibly, by heightening the effects of male socialization and advancing (social) age, stints in this institution, destined for the training of political, intellectual and administrative elites, and particularly known for the value it places on "general knowledge" (Bourdieu 1996; Garrigou 2016), are conducive to the internalization of a disposition to feel authorized to publicly speak out on political questions in ways that concur with the worldviews (and conceptions of the intellectual's role) of the journalistic elite, whose members have themselves often been trained by the very same institution (Lafarge \& Marchetti 2011).

\section{Intellectuals with an Appetite for Public Debate}

31 In a way that is consistent with the previous observation, the academics and researchers in our population often share a specific conception of scholarly activity, strongly geared towards general political and topical debates. Looking at their past 
publications, we can see that, over the 2000-2014 period, more than half of them published at least one article in one of a small group of generalist intellectual reviews, including Esprit, Le Débat, Commentaire, Les Temps modernes, Mouvements, Vacarme, Multitudes, Revue Projet, and Cités. Even if we only consider one of them, Le Débat, launched in 1980 (and discontinued in 2020) by Pierre Nora to, in his own words, "combat [...] media reductiveness on the one hand, and academic specialization on the other"14, we find that nearly 20 individuals in our population published there between 2000 and 2014.

It is also worth noting that the individuals in our corpus are only in exceptional cases new voices in the media (including television). In an illustration of the prescriptive power conferred by presence on TV (Bourdieu 1998), among the 77 authors who are French or work in France, 64 were featured at least once on French television between 2000 and 2014 (over 80\%). Here we observe the well-documented phenomenon through which a small group of persons tend to be repeatedly invited and over-exposed in the media (Jeanpierre \& Mosbah-Natanson 2008; Malherbe \& Luce 2017). This is clearly evidenced, for instance, by the fact that among the individuals in our population, seven contributed to several different articles (even though the period under study spanned only one month), such as the consultant Yves Bertoncini and the political scientist Thomas Guénolé. The same phenomenon is also visible in the "Matthew effect" (Merton 1968) that can be observed when searching each author of our population in the French audiovisual archives over the 2000-2014 period: in the small group of the most frequent guests on radio or on television, the number of appearances is significantly higher. (Figure 6).

Fig. 7.

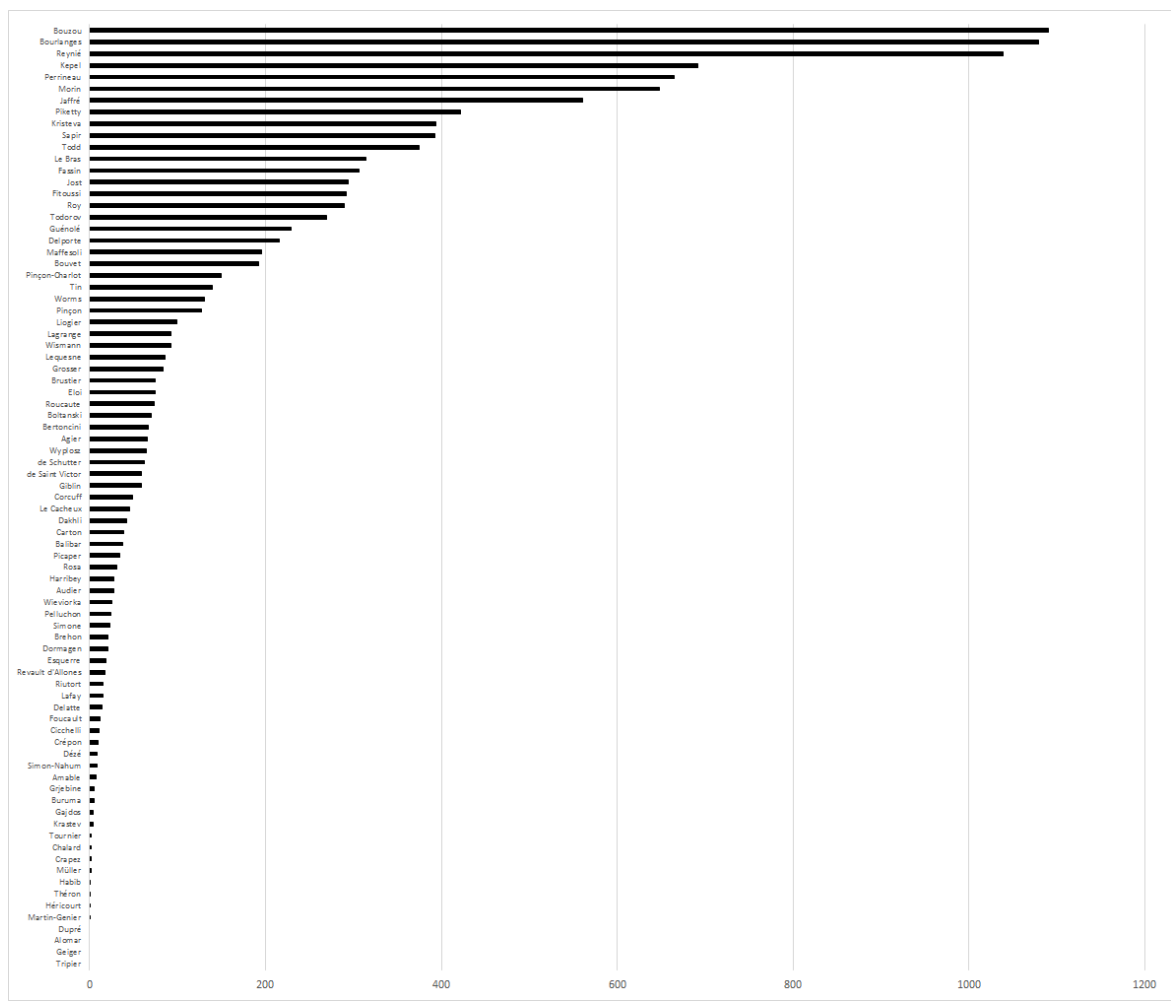

Number of TV and radio appearances for each author in our population (2000-2014)

Source: French National Audiovisual Institute - INA 
33 political scientists (or economists) such as Nicolas Bouzou (1,090 entries), Jean-Louis
Bourlanges (1,079), Dominique Reynié (1,039) - which is often the result of being a
columnist in a TV or radio show ${ }^{15}$. Other authors in our population are rather
characterized by their high numbers of talk-show appearances (Malherbe \& Luce 2017).
Over the 2010-2015 period, for instance, sociologist Michel Maffesoli ( 22 appearances),
political scientist Gilles Kepel (23), demographer and historian Emmanuel Todd (25),
economist Thomas Piketty (28), political scientist Thomas Guénolé (30) and sociologist
Eric Fassin (96) were all frequently recurring guests.
Lastly, when they intervene in the main national daily newspapers, the academics and
researchers under study are sometimes quite far from the figure of the specialized
expert, akin to Foucault's "specific intellectual". While we have not retraced each
author's history of all their public interventions, our corpus contains several examples
of interventions that fall outside what might be considered the author's area of
expertise. These include the demographer and historian Emmanuel Todd claiming in an
interview that "the Euro is a proven failure", and the economist Nicolas Bouzou citing
the "anti-globalisation obsession" of the "losers of globalization" as the reason for the
Front National's high score. The term "total expert", recently introduced in reference
to economists, whose conceptual toolbox allows them to present an ostensibly
scholarly discourse on a very wide array of subjects (Lebaron 2017), seems like a more
appropriate characterization of a number of authors in our population. Fig. 8.

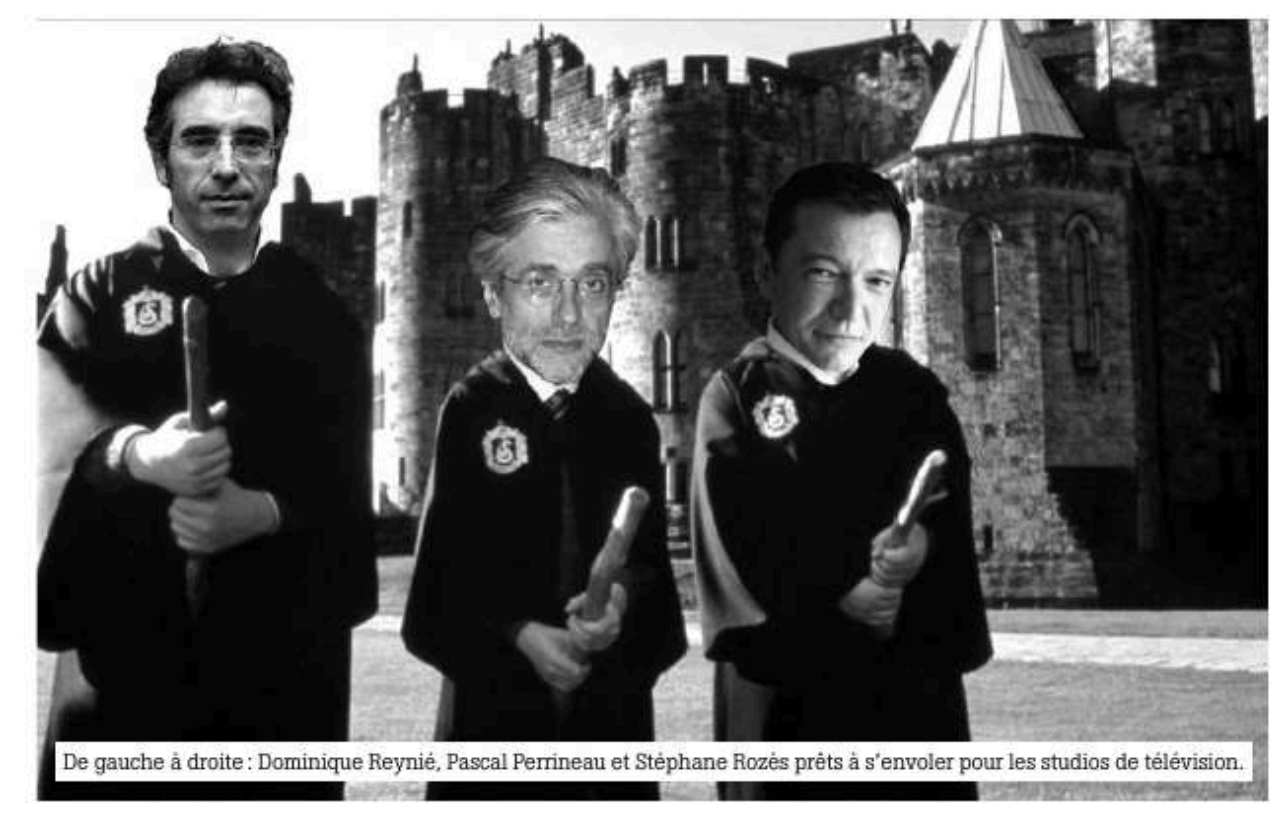

« Dominique Reynié, Pascal Perrineau and Stéphane Rozès ready to take off to the TV studios » Source: Le Plan B n²3 (mai-juin 2010), journal de critique des médias (2006-2010). 


\section{Intersecting the Academic, Political and Journalistic Fields} academics would be incomplete if we failed to mention that they tend to combine several institutional and sometimes professional affiliations: they may be both a university professor and a columnist, a journalist, an essayist, a magistrate, a CEO, a consultant, a political advisor, etc. In other words, many of the people who are presented as scholars in their interventions in the national daily press are themselves multi-positioned (Boltanski 1973) at the intersection of a variety of fields, beginning with the academic, journalistic and political fields.

An example of this is Dominique Reynié: a holder of the agrégation (France's most selective teaching qualification) in political science and former member of its jury, professor at Sciences Po Paris, the author or editor of many scientific books and articles in key French political science journals (such as Raisons politiques and Politix); he is also a (right-wing) politician, the director of a think tank called the "Foundation for Political Innovation" (Fondapol), an expert for the European Commission, a former columnist on the public radio France culture ("The world according to Dominique Reynié") and a regular guest in TV talk-shows, like $C$ dans l'air.

In addition to the previously mentioned group of the columnists, we also find some individuals who previously worked as journalists (such as Jean-Paul Picaper and Alfred Grosser) and others known for their engagement in party politics, like Yves Roucaute (who was a member of several right-wing ministerial cabinets), Philippe Corcuff (formerly of the Parti Socialiste, of Les Verts [the Green Party], of the Ligue Communiste Révolutionnaire, and currently a member of the Anarchist Federation) or Laurent Bouvet (previously a representative of the "Gauche populaire", a movement with connections with the Parti Socialiste, he has since launched a centre-left political movement, centred on the defence of secularism, the "Printemps républicain"16).

In some cases, particularly for some specialists of European matters, there is a more tenuous or indirect relation to the academic field. This concerns a significative part of the magistrates, parliamentarians, civil servants and consultants who, because they also do lectures in higher education institutions - particularly in top schools like Sciences Po Paris -, can claim an academic affiliation. Sometimes their different professional endeavours are presented jointly. Jean-Louis Bourlanges's political career as a centrist member of the European Parliament, is for instance mentioned in addition to his status as an "associate professor at Sciences Po". Likewise, Massimo Cacciari is presented as a "philosopher" and "ex-mayor of Venice" and Yves Bertoncini as the "Director of Notre Europe-Jacques Delors" ${ }^{17}$ and a "lecturer at the École des Mines" [which is a very selective French engineering school] who "wrote numerous books on European matters". Conversely, in the case of pieces by Patrick Martin-Genier, Bruno Alomar, Nicolas Jean-Brehon or Nicolas Bouzou, the signatures only include a single affiliation: "maitres de conférence at Sciences Po Paris" for the former two (who respectively work as a magistrate and a "management consultant"), "lecturer at [University] Paris 1 Panthéon-Sorbonne" for the third (who mostly works as a parliamentary official and columnist for Le Monde's supplement on economic issues), and "economist" for the latter (who is the founder and director of the Asteres consultancy firm and an essayist). 
Depending on the cases, then, the multi-positioning is highlighted, being a possible source of prestige, especially when the author combines different titles that justify access to public expression on a number of subjects; or conversely, it is concealed so that the symbolic capital derived from the scholarly title is the only one retained, particularly in the case of lesser known authors, or those whose teaching activities are best suited than their other activities, to legitimating their public expression.

\section{Conclusion}

40 Applied to the interventions of HSS academics and researchers in the press during an electoral campaign, the concept of expertise suffers from several limitations. On one level, these interventions, when legitimated by a scholarly identity (or even by a specialization in an area of research), steer clear of claiming partisan affiliations and opt instead for broader recommendations, thus reflecting a disciplinary division of areas of expertise. However, while journalists themselves appear to promote the model of the "expert" by highlighting scholarly titles or by letting a few fairly young and little-known authors contribute, other constraints and rationales favour more traditional models of engagement. For instance, the logic of the hierarchization of exposure in the generalist press is conducive to the over-exposure of a small number of authors who are prone to expressing themselves on a variety of topics, acting, if not as "universalist intellectuals" in the manner of Sartre, at least as "generalist experts".

41 Additionally, because of strictly journalistic constraints but also to the dispositions of authors who are keen to adhere to these parameters, we find that it is difficult to approach the discursive registers used in these texts in terms of expertise. This is not only because the opinion piece, a genre that calls on the freedom of expression of the "universalist" intellectual, appears to remain the form of choice for HSS academics and researchers who contribute to the national daily press; but also because, upon examination of our corpus, we found that there is no radical opposition between opinion pieces and other forms of print contributions such as interviews: with each of these formats, the reader tends to doxically embrace the arguments laid forward. In other words, to judge the quality of these interventions, the reader can only rely on the apparent consistency of the argument (meaning their own pre-formed categories of political judgment), their disposition towards "scholars" (considered either as a whole, or individually depending on whether they are familiar with the author's name), or the political connotations associated with a given discipline. These press interventions - as "expert" contributions, or at any case, legitimated as such - consist in the appropriation of the symbolic capital collectively held by HSS academics and researchers as a group. This in turn points to the risk of a devaluation of this collective capital inherent in its individual use, when prophecy masquerades as expertise. 


\section{BIBLIOGRAPHY}

ABвотT Andrew (1988). The System of Professions. An Essay on the Division of Expert Labor. Chicago, University of Chicago Press.

BOLTANSKI Luc (1973). “L'Espace positionnel: multiplicité des positions institutionnelles et habitus de classe". Revue française de sociologie, 14(1): 3-26.

BOURDIEU Pierre (1971). “Une Interprétation de la théorie de la religion selon Max Weber". European Journal of Sociology/Archives Européennes de Sociologie/Europäisches Archiv für Soziologie, 12(1): 3-21.

BOURDIEU Pierre (1984). « Le Hit-parade des intellectuels français ou qui sera juge de la légitimité des juges?». Actes de la recherche en sciences sociales 52(1): 95-100.

BOURDIEU Pierre (1988) [1984]. Homo academicus. English translation by Peter Collier. Palo Alto, Stanford University Press.

BOURDIEU Pierre (1991) [1988]. The Political ontology of Martin Heidegger. English translation by Peter Collier. Palo Alto, Stanford University Press.

BOURDIEU Pierre (1996) [1989]. The State nobility: Elite schools in the field of power. English translation by Lauretta C. Clough. Palo Alto, Stanford University Press.

BOURDIEU Pierre (1998) [1996]. On Television. English translation by Priscilla Parkhurst. Ferguson, New York, New Press.

BOURDIEU Pierre 2020 [2011]. "The Field of Power and the Division of the Labour of Domination". Traduction anglaise par Jean-Yves Bart. In DENORD Francois, PALME Mikael, RÉAU Bertrand (eds.). Researching Elites and Power: Theory, Methods, Analyses. Cham, Springer International Publishing: 33-44.

BOUTIER Jean, PASSERON Jean Claude, REVEL Jacques (2006). Qu'est-ce qu'une discipline. Paris, École des hautes études en sciences sociales, coll. "Enquête ", 5.

CHARLE Christophe (1990). Naissance des “intellectuels," 1880-1900. Paris, Éditions de Minuit.

COLLOVALD Annie (1988). “Identité(s) stratégique(s)." Actes de la recherche en sciences sociales, 73: 29-40.

DELMAS Corinne (2006). Instituer des savoirs d'État. L'Académie des sciences morales et politiques. Paris, L'Harmattan.

DENORD François, LAGNEAU-YMONET Paul, THINE Sylvain (2011). "Le Champ du pouvoir en France." Actes de la recherche en sciences sociales, 190: 24-57.

DÉSINTOX (Association de citoyens contre la désinformation) (2004). Du Bon usage des tribunes du Monde. La Désinformation - La preuve, 4, Paris.

DUCLERT Vincent (1999). “L’Engagement scientifique et l'intellectuel démocratique. Le sens de l'Affaire Dreyfus." Politix, 48: 71-94

DULLER Matthias, KOROM Philipp, sCHÖGLER Rafael Y., FLECK Christian (2018). "Scholars as European public intellectuals? Media interventions in the 2014 European Parliament election campaign." European Societies, 20(2): 322-353. 
DUVAL Julien, GAUBERT Christophe, PAVIS Fabienne, LEBARON Frédéric, MARCHETTI Dominique (1998). Le "Décembre" des intellectuels français. Paris, Liber-Raisons d'Agir.

FRANÇOIS Bastien \& NEVEU Érik (1997). "Pour une sociologie politique des espaces publics contemporains". In FRANÇoIS Bastien \& NEVEU Erik (eds.). Espaces publics mosaïques. Acteurs, arènes et rhétoriques des débats publics contemporains. Rennes, Presses universitaires de Rennes: 13-58. GARRIGOU Alain (2001). “La 'Pensée Sciences Po'.” In Les élites contre la République: Sciences Po et l'ENA. Paris, La Découverte: 79-112.

GAYON Vincent (2012). “Jeu critique : la 'fin des intellectuels' (1975-1985).” Le Mouvement Social, 239: 25-44.

GINGRAS YVES (1991). "L'Institutionnalisation de la recherche en milieu universitaire et ses effets." Sociologie et sociétés, 23(1): 41.

HEILBRON Johan (2004). "A regime of disciplines: toward a historical sociology of disciplinary knowledge." In CAMIC Charles \& JOAs Hans (eds.). The dialogical turn: new roles for sociology in the postdisciplinary age. Lanham, MD, Rowman \& Littlefield: 23-42.

JEANPIERRE Laurent (2016). “Tribunes et plateaux: logiques de la visibilité intellectuelle.” In CHARLE Christophe \& JEANPIERRE Laurent (eds.). La Vie intellectuelle en France, t. 2 (De 1914 à nos jours). Paris, Seuil: $494-500$.

JEANPIERRE Laurent \& MOSBAH NATANSON Sébastien (2008). "French Sociologists and the Public Space of the Press: Thoughts Based on a Case Study (Le Monde, 1995-2002)." In FLECK Christian, HESS Andreas, LYON E. Stina (eds.). Intellectuals and their Publics, Perspectives from the Social Sciences. Farnham/Burlington, Ashgate Publishing: 173-192.

JOLY Marc (2017). La Révolution sociologique. De la naissance d'un régime de pensée scientifique à la crise de la philosophie (XIX ${ }^{e}-X^{e}$ siècles). Paris, La Découverte.

LAFARGE Géraud \& MARCHETTI Dominique (2011). "Les Portes fermées du journalisme: L'espace social des étudiants des formations ' reconnues '." Actes de la recherche en sciences sociales, 189: 72. LEBARON Frédéric (2017). “L'Économiste ou l'invention de 'l'expert total'." Bulletin du Snesup, 655: 14.

LENSING-HEBBEN Caroline (2008). Les Experts cathodiques. Chercheurs face à la tentation médiatique. Paris, Le Bord de l'eau/INA.

MALHERBE Clément \& LUCE Raphaël (2017). “Invités des talk-shows et émissions de divertissement : tous les mêmes? La revue des médias". (Accessed on 23 juillet 2020.)

MATONTI Frédérique (2002). "La Colombe et les mouches. Frédéric Joliot-Curie et le pacifisme des savants." Politix, 58: 109-140.

MATONTI Frédérique \& SAPIRO Gisèle (eds.) (2009). “L'Engagement des intellectuels, nouvelles perspectives.” Actes de la recherche en sciences sociales, 176-177: 4-7.

MAYAFFRE Damon (2005). "Les Corpus politiques: objet, méthode et contenu." Corpus, 4. (Accessed on 23 juillet 2020.)

MEMMI Dominique (1989). "Savants et maîtres à penser. La fabrication d'une morale de la procréation artificielle.” Actes de la recherche en sciences sociales, 76: 82-103.

MERTON Robert K. (1968). “The Matthew Effect in Science.” Science, 3810: 56-63.

NOIRIEL Gérard (2010). Dire la vérité au pouvoir: les intellectuels en question. Marseille, Agone. 
PINTO Louis (2002). “L'Espace public comme construction journalistique. Les auteurs de 'tribune' dans la presse écrite." Agone, 26-27 : 151-182.

SAPIRO Gisèle (2009). "Modèles d'intervention politique des intellectuels: Le cas français." Actes de la recherche en sciences sociales, 176-177: 8-31.

SAPIRO Gisèle, BRUN Éric, FORDANT Clarisse (2018). "The Rise of the Social Sciences and the Humanities in France; Institutionalization, Professionalization, Autonomization". In FLECK Christian, DULLER Matthias, KARADY Viktor (eds.). Shaping Human Science Disciplines. Institutional Development in Europe and Beyond. Cham, Palgrave MacMillan: 25-68.

SIMÉANT Johanna (2002). "Friches, hybrides, et contrebandes : sur la circulation et la puissance militantes des discours savants”. In HAMMAN Philippe, MÉON Jean-Mathieu, VERRIER Benoit (eds.). Discours savants, discours militants: mélange des genres. Paris, L'Harmattan: 17-53.

soulié Charles (2013). “Des humanités à 'l'économie de la connaissance'? Les transformations du corps enseignant en lettres et sciences humaines en France (1949-2010)". In CONESA Marc, LACOUR Pierre-Yves, ROUSSEAU Frédéric, THOMAS Jean-François (eds.). Faut-il brûler les Humanités et les Sciences humaines et sociales?. Paris, Michel Houdiard Éditeur.

\section{NOTES}

1. In this article, we define "expertise" not as the act of responding to an institutional commission, but more broadly as a mode of public intervention made in the name of a specialized, established area of knowledge. In other terms, what we call here an "expert" is close to a figure with which experts are sometimes contrasted (Noiriel 2010): the "specific intellectual" as theorized by Michel Foucault.

2. Here, "humanities and social sciences" (HSS) refers to a group of scholarly disciplines that differ from the so-called "natural" sciences. This category, which is institutional in origin, admittedly has the downside of amalgamating disciplines whose methods, objects and, in some cases, objectives may vary quite widely. We use it however precisely for the purpose of comparing academics and researchers coming from different disciplinary traditions that themselves share a scholarly dimension and a vocation to discuss the social life of humans (through more or less explicative, normative, empirical or theoretical approaches). Our corpus accordingly includes sociologists, political scientists (who in France tend to be called "politologists" outside of academic circles), economists, demographers, geographers, historians, anthropologists, linguists, as well as philosophers and legal scholars.

3. Although it is frequently referred to in public debates, this principle is not mentioned in the text that has defined the general status of civil servants in France since 1983, being a construct of administrative case-law that has made its way into some statuses. The independence and freedom of speech of lecturers and researchers is guaranteed by Article L. 952-2 of the Education Code which remained in force at the time of writing: "Lecturers/researchers, lecturers and researchers shall enjoy total independence and complete freedom of speech in the performance of their teaching duties and research activities, provided that they respect the principles of tolerance and objectivity, in accordance with academic traditions and the provisions of the present Code."

4. Research leading to these findings was funded by the European Union's seventh Framework Programme (FP7/20072013) under Grant Agreement no. 319974 (Interco-SSH).

5. The Front National is the main French far-right party. Since 2018, it has been called Rassemblement National. 
6. The Parti Socialiste is the main French centre-left party.

7. The Union pour la Majorité Présidentielle, then Union pour un Mouvement Populaire, is the main French centre-right party. It took the name "Les Républicains" in 2015.

8. The Observatoire du changement politique is a private company in charge of market research and surveys, particularly electoral surveys. No new information has been published on the company from November 2016.

9. As for the discipline-based distribution of subjects addressed, this well-ordered division is evidently subject to a few exceptions, such as the presence of Nicolas-Jean Brehon - who appears to be more of an economist but penned an electoral analysis - among the political scientists.

10. Notable exceptions include the economist Thomas Piketty's opinion piece in Libération entitled "Citizen, to the polls!", expressing a clear preference for the candidate Schulz, and the call to vote "for Europe" by the politologist-journalist Jean-Paul Picaper and the lawyer Alain Terrenoire in an interview in Le Figaro.

11. Mentioning a book on the subject addressed in the article can serve as a way of outsourcing evidence production. However, the books in question, according to their authors themselves, are more often akin to essays than scientific publications.

12. If, among the 77 authors in our population who are French or work in France, we exclude Legion of Honour recipients, those with their own Who's Who entry, and those who were invited at least 50 times to speak on French TV and radio between 2000 and 2014 (based on the number of entries matching their name in the databases of the French Audiovisual Archives INA [Institut National de l'Audiovisuel]) we have only 31 individuals left.

13. Project Syndicate is the self-proclaimed "World's Opinion Page", offering news commentaries in thirteen languages by "prominent political leaders, policymakers, scholars, business leaders, and civic activists from around the world". Its contributors include 45 Nobel Prizes and 111 heads of State and government. According to its website, it is funded mainly by the Bill and Melinda Gates Foundation and the European Climate Foundation.

14. See Pierre Nora's présentation of Le Débat on its publisher's website (Gallimard).

15. For instance, many of the entries for Nicolas Bouzou refer to a handful of shows - namely the "Teamtoussaint" morning show and "La Newsroom" on I-Télé (a French 24-hour news channel), where he was the resident commentator on economics. More largely, it is frequently the case that a high number of entries relates to a small group of shows.

16. See the " manifest » of the movement.

17. It is a think tank founded by Jacques Delors (a significant leader in the history of the EU's political construction) in 1996.

\section{ABSTRACTS}

By analysing the interventions of humanities and social sciences (HSS) researchers and academics in national daily newspapers during the 2014 European electoral campaign, this article sheds new light on the development of "expertise" as a form of engagement of intellectuals in public space. While these scholars may be expected to lend their expertise, are they effectively doing this when they contribute to national generalist newspapers? This study focuses on the pieces they authored in the prominent newspapers Le Monde, Libération et Le Figaro - op-eds, interviews, columns, and analytical articles. The qualitative and quantitative study of the content 
of these productions reveals that discourses are rooted in the authors' disciplines, but also, especially after the election results, that they manifest an inclination towards prophecy. While they leave little room for well-argued demonstration, newspaper articles draw their legitimacy from the expert competencies displayed by the author and collectively guaranteed by researchers as a professional body. In this limited framework, this collective capital point is at risk of being instrumentalized and/or devalued when used individually.

L'analyse des interventions des chercheurs et universitaires en sciences humaines et sociales dans la presse quotidienne nationale française durant les élections européennes de mai 2014 permet d'interroger à nouveaux frais le développement de "l'expertise " comme forme d'engagement des intellectuels dans l'espace public. On pourrait s'attendre à ce que les savants privilégient une telle forme d'engagement, mais le font-ils effectivement lorsqu'ils interviennent dans la presse généraliste nationale? L'étude porte sur les articles qu'ils signent dans les journaux Le Monde, Libération et Le Figaro, qu'il s'agisse de tribunes, d'interviews ou encore de chroniques et d'articles d'analyse. En faisant une étude à la fois qualitative et quantitative du contenu de ces différentes productions, on révèle un ancrage des discours dans les disciplines d'appartenance des auteurs, mais également, et en particulier après les résultats de l'élection, une propension au prophétisme. Laissant peu d'espace à l'administration de la preuve, la légitimité de l'article de journal repose pourtant sur les compétences expertes arborées par son auteur et collectivement garanties par la catégorie professionnelle des chercheurs; dans ce cadre contraint, les usages individuels de ce capital collectif exposent du même coup au risque de son instrumentalisation et/ou de sa dévalorisation.

\section{AUTHORS}

\section{CONSTANTIN BRISSAUD}

École des hautes études en sciences sociales (EHESS)/Centre européen de sociologie et de science politique-Centre européen de sociologie (Cessp-CSE)

\section{ÉRIC BRUN}

École des hautes études en sciences sociales (EHESS)/Centre européen de sociologie et de science politique-Centre européen de sociologie (Cessp-CSE) 